\title{
The influence of body position on Bielschowsky's test
}

\author{
A influência da posição corporal sobre o teste de Bielschowsky
}

Carlos R. Souza-Dias ${ }^{1}$, Mauro Goldchmitio ${ }^{1,2}$, Fabio P. Moraes ${ }^{2}$, Arthur Jampolsky $^{3}$

\begin{abstract}
Purpose: To investigate the veracity of Jampolsky's statement that Bielschowsky's head tilt test is inverted if performed with the patient in the upside-down position and to interpret its neuromuscular mechanism.

Methods: We present a series of 10 patients selected from a referred sample who were diagnosed with superior oblique paresis. Hypertropia was measured in the primary position, with the head erect and tilted toward both shoulders with the patient in the erect, supine, and upside-down positions. The last position was achieved by hanging the patient upside-down.

Results: As expected, our results showed the veracity of Jampolsky's statement. The forced head tilt difference was inverted or significantly decreased when the test was performed in the upside-down position. Moreover, in all patients, Bielschowsky's phenomenon was neutralized in the supine body position, in which hypertropia with the head erect tended to vanish. In 3 patients, it disappeared completely.

Conclusions: This study showed that, in patients with superior oblique paresis, differences in the extent of hypertropia in Bielschowsky's test tended to vanish when the test was performed with the patient in the supine position and invert when it was performed with the patient in the upside-down position.
\end{abstract}

Keywords: Strabismus; Body positioning; Troclear nerve; Ophthalmoplegia

\section{RESUMO}

Objetivo: Investigar a veracidade da suposição de Jampolsky de que o teste de inclinação da cabeça de Bielschowsky inverte-se caso seja realizado com o paciente de cabeça para baixo, e tentar interpretar o mecanismo neuromuscular envolvido.

Métodos: Apresentamos uma série de 10 pacientes portadores de paresia do oblíquo superior. Foi medida a hipertropia dos pacientes na posição primária do olhar e com a cabeça inclinada para cada um dos lados nas posições ereta, supina e de cabeça parabaixo.

Resultados: Comoesperado, nossos resultados confirmaram a suposição de Jampolsky; além disso, e em todos os pacientes, o fenômeno de Bielschowsky foi neutralizado em posição supina. As diferenças da magnitude da hipertropia ao teste de Bielschowsky diminuiram significativamente ou inverteram-se quando o paciente foi testado de cabeça para baixo.

Conclusões: Este estudo demonstrou que, nos pacientes com paresia do oblíquo superior, a hipertropia evidenciada pelo teste de Bielschowsky tende a desaparecer com o paciente na posição supina e a se inverter quando o teste é realizado com o paciente de cabeça para baixo.

Descritores: Estrabismo; Posicionamento do paciente; Nervo troclear; Oftalmoplegia

\section{INTRODUCTION}

The compensatory head tilt during certain oculomotor anomalies has the goal of reducing hypertropia, avoiding diplopia, and maintaining fusion ${ }^{(1)}$.

The forced head tilt difference means the difference in the magnitude of vertical deviations when hypertropia is measured with the head tilted toward both shoulders; this primarily occurs in patients with superior oblique paresis and superior rectus contracture (Jampolsky's syndrome $\left.{ }^{(2)}\right)$. In 1985, David Robinson ${ }^{(3)}$, after a mathematical analysis of his Robinson's model of the oculomotor plant with regard to large vertical deviations in the head tilt test, concluded that only a contractured superior rectus muscle could account for such a large forced tilt difference in some patients with superior oblique palsy.

The conventional mechanical explanation for Bieslschowsky's test ${ }^{(4)}$ is based on the otolith static reflex, which is responsible for the counter-rolling of eyes induced by head tilting toward the shoulders. When the head is tilted toward the right shoulder, for instance, the right eye tends to incycloduct, which is induced by the otolith system, through the innervation of its intorsional muscles, namely the superior rectus and superior oblique muscles. These muscles are antagonists in vertical and horizontal actions; therefore, when they are simultaneously innervated, they compensate for each other and result in no vertical or horizontal eye movement. However, they are synergistic when it comes to torsion. When they are simultaneously innervated by right head tilting, as in the case of right superior oblique palsy, the superior rectus muscle overcomes the depressor action of the weakened superior oblique muscle and elevates the eye $\mathrm{e}^{(5)}$.

Jampolsky stated, in 1994(6), that if Bielschowsky's test is performed with the patient in an upside-down position, the forced tilt difference would give a mirror image, that is, an inverted one. This led to interesting speculations about the otolith mechanism and the muscular mechanics of the forced head tilt difference.

This study aimed to investigate the veracity of this statement and interpret the underlying neuromuscular mechanism. Patients with superior oblique paresis were selected, and the deviation with the head tilted to both sides was measured with the patient in the erect, supine, and upside-down positions.
Funding: This study was supported by a grant from the Smith Kettlewell Eye Research Institute. Disclosure of potential conflicts of interest: None of the authors have any potential conflicts of interest to disclose.

Corresponding author: Carlos R. Souza-Dia. Rua Cincinato Braga, 59 - Cj. 5 B2 - São Paulo (SP) 01333-011 - Brazil - E-mail: csdias@uol.com.br

Research Ethics Committee: Approved by the Comitê de Ética e Pesquisa of the Santa Casa de Misericórdia de São Paulo under the number 364/11. 


\section{METHODS}

This work was approved by the Ethics Committee of the Faculty of Medical Sciences of the Santa Casa de Misericórdia of São Paulo under the number 364/11. After the procedure was explained to the subjects (or legal guardians for minors) and accepted by free will, informed consent was obtained.

Ten patients [8 unilateral and two asymmetric bilateral (Patients 7 and 10), Table 1] consecutively examined in the Santa Casa and CEMA hospitals who presented with the clinical picture of superior oblique paresis were prospectively examined. The mean age was $31.4 \pm 15.3$ years ( $9-52$ years).

The data necessary for diagnosing unilateral superior oblique paresis included the following: hypertropia of the affected eye that increased on the contralateral side with the head tilted toward the ipsilateral shoulder and decreased on ipsilateral side with the head tilted toward the contralateral shoulder (Bielschowsky's test), excyclotropia, and a V-anisotropia. Asymmetric superior oblique paresis was diagnosed according to the criteria discussed by Souza-Dias in another paper ${ }^{(7)}$.

For this research, we measured the deviations in the primary position with the head erect and maximally tilted to both shoulders, with the patient in the erect, supine, and upside-down positions. Ipsilateral superior rectus contracture was investigated during surgery with the forced duction test ("knife-edge" maneuver, proposed by Jampolsky in $\left.1978^{(8)}\right)$.

After external, anterior segment, and fundus examinations and refractometry, a thorough ocular motility examination was performed, with special attention to the alternate prism and cover test in all positions of gaze and in the primary position with the head tilted toward both shoulders. All patients possessed 40 " to 50 " of stereoacuity, which was assessed using the Titmus Fly Test ${ }^{\circledR}$ (Titmus Optical, Petersburg, VI, USA), or were able to recognize the 3 figures on Lang's test. All patients showed extorsion of the affected eye as diagnosed by the double Maddox test and, in some of them, fundoscopy.

The upside-down position was achieved in the 2 young patients by an adult hanging them by the legs and in the remaining 8 adults by utilizing a special slanting bed that was specifically built for this investigation (Figure 1).

In order to avoid misunderstanding, let us define 2 terms. Hypertropia of an eye indicates that the affected eye is deviated toward the top of the head, and hypotropia of an eye indicates that the affected eye is deviated toward the feet, regardless of the patient's body position.

\section{RESULTS}

In all patients, the forced head tilt difference was neutralized or tended to vanish when the test was performed with the patient in the supine position, while it was inverted or significantly decreased in magnitude when the patient was in the upside-down position.

As seen in table 1, there was a complete inversion (Patient 2) or an almost complete inversion (Patient 3) of the forced head tilt difference when the test was repeated with the patient in the upside-down position. In all the other patients, there was a clear tendency for inversion. In Patient 1, for instance, the left hypertropia with the head tilted toward the right shoulder increased from $8^{\Delta}$ to $25^{\Delta}$, thus increasing by $17 \Delta$, while that with the head tilted toward the left shoulder decreased from $35^{\Delta}$ to $15^{\Delta}$, thus decreasing by $20^{\Delta}$. The forced tilt difference that measured $27^{\Delta}$ was reduced to $10^{\Delta}$, but in the opposite sense (it was inverted). Therefore, the total change was $37^{\Delta}$. In Patient 10, the hypertropia disappeared in the supine and upside-down positions.

When the test was repeated with the patients in the supine position, the forced head tilt difference tended to disappear in all patients. It was noteworthy that the hypertropia in the primary position tended to vanish when tested with the head erect and the body in the supine position. In Patients 3 and 10, the hypertropia disappeared. In Patient 9 , in these body and head positions, there was a tendency for inversion of Bielschowsky's test, but the hypertropia in the primary position remained (it was only decreased).

The measurement of the forced head tilt difference in the 10 patients in the primary position; with the body erect, supine, and upside-down; and with the head erect and tilted toward both shoulders are listed in table 1.

\section{DISCUSSION}

If the otolith mechanism is considered as the explanation for the forced head tilt difference, it is not difficult to explain the disappearance of the hypertropia when the patient is in the supine position. A probable explanation is that if the head is tilted toward the shoulders with the patient in this position, the hypertropia does not appear because the otoliths stimulate other areas inside the utricule; furthermore, the force $\mathrm{G}$ vector (gravity) does not change its relative direction within the utricle with the change in head position. It is more difficult to explain the tendency for the decrease in the magnitude of the hypertropia in the primary position with the patient in the supine position. Till date, no study regarding this phenomenon has been published. A possible mechanism is relaxation of all the

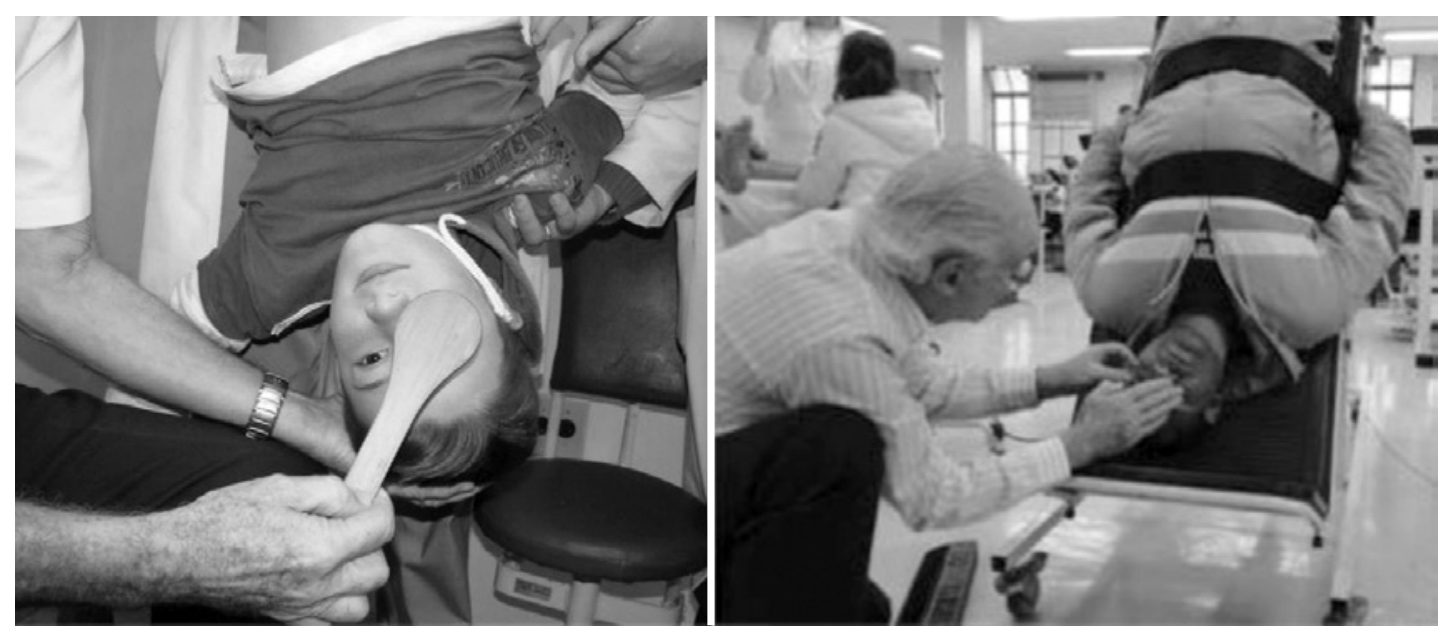

Figure 1. The method for measuring hypertropia with the patients in the upsidedown position. The boy is hung from the legs by an adult, while the adult is strapped in a slant stretcher designed for this purpose. 
Table 1. Measurement of hypertropia in the 3 head positions of Bielschowsky's test (erect and tilted toward each of the shoulders), with the patients in the erect, supine, and upside-down positions

\begin{tabular}{|c|c|c|c|c|c|c|c|c|c|}
\hline \multirow[b]{5}{*}{ Patients } & \multicolumn{9}{|c|}{ Bielschowsky's test } \\
\hline & \multicolumn{9}{|c|}{ Body position } \\
\hline & \multicolumn{3}{|c|}{ Erect } & \multirow{2}{*}{\multicolumn{3}{|c|}{$\begin{array}{c}\text { Supine } \\
\text { Head position }\end{array}$}} & \multicolumn{3}{|c|}{ Upside-down } \\
\hline & & & & & & & & & \\
\hline & Right & Erect & Left & Right & Erect & Left & Right & Erect & Left \\
\hline 1 & -8 & -25 & -35 & & & & -25 & & -15 \\
\hline 2 & -3 & & -25 & -5 & & 0 & +25 & & -3 \\
\hline 3 & +25 & +5 & 0 & 0 & 0 & 0 & 0 & & +20 \\
\hline 4 & 0 & -10 & -12 & -2 & -6 & -12 & -3 & & -5 \\
\hline 5 & +25 & +25 & +6 & +3 & +3 & +3 & +12 & +20 & +20 \\
\hline 6 & -3 & -4 & -15 & -6 & -5 & -5 & -12 & -10 & -13 \\
\hline 7 & +15 & +8 & -6 & +5 & 0 & +7 & 0 & +2 & +5 \\
\hline 8 & -4 & -15 & -15 & -6 & -5 & -5 & -12 & -12 & -3 \\
\hline 9 & 0 & -22 & -40 & -12 & -15 & -25 & -15 & -12 & 0 \\
\hline 10 & +15 & +8 & -4 & 0 & 0 & 0 & 0 & 0 & 0 \\
\hline
\end{tabular}

The measurements are in prism diopters. The symbol" + "indicates right hypertropia, while the symbol "-" means left hypertropia. The affected eye is indicated by the side of the larger hypertropia in Bielschowsky's test in the erect body position.

cyclovertical muscles in this position. Its permanence, with only a small decrease in Patient 9, was probably caused by an ipsilateral superior rectus contracture.

However, in the upside-down position, the sense of the force $G$ vector into the utriculi is inverted, and it is not known if there is such an inversion mechanism in the utriculi. The otoliths stimulate an opposite area. Furthermore, considering the mechanical reasoning for the forced head tilt difference described above, with the patient in the upside-down position, for the right eye to move toward the, the case of a right superior oblique palsy, there would have to be an imbalance of the vertical forces between the ipsilateral inferior rectus and inferior oblique of this eye (a weakness of the inferior oblique), for the inferior rectus to overcome its elevating action, and depress the eye, which did not exist in this case. On the contrary, in patients with superior oblique palsy, there is generally an ipsilateral inferior oblique overaction that can elevate the eye (to move toward the top of the head) instead of depressing it (to move toward the feet).

It is noteworthy that Wong et al. ${ }^{(9)}$ found different data. In patients diagnosed with skew deviation, hypertropia decreased by $>50 \%$ when measurements performed with the head erect and in the supine position were compared. This was in contrast with the findings for patients with superior oblique palsy, in whom this decrease was smaller or absent. In all 8 patients who underwent measurements in the supine position, there was a decrease or disappearance in the forced head tilt difference; the hypertropia in the primary position disappeared in 3 and decreased in the remaining, except in Patient 9 (Table 1).

In conclusion, the behavior of the cyclovertical extraocular muscles during static head tilt toward the shoulders with the patient in the upside-down and supine positions remains to be elucidated. This lack of knowledge suggests, as pointed out by Jampolsky in 1994(6) that the neurophysiology of the static vestibulo-ocular reflexes and clinical head tilt test interpretations should be re-examined. The findings also explain the fact that the so-called Parks' test frequently fails to diagnose diseases of the other cyclovertical muscles other than superior oblique palsy, as pointed out by Bicas \& De Sordi ${ }^{(10)}$, Prieto-Díaz \& Souza-Dias ${ }^{(11)}$, and Souza-Dias \& Goldchmit ${ }^{(12)}$.

\section{ACKNOWLEDGEMENT}

The authors acknowledge Dr. Roberto Mitiaki Endo for his assistance in the submission of this work to the Ethics Committee.

\section{REFERENCES}

1. Khawan E, Scott AB, Jampolsky A. Acquired superior oblique palsy. Arch Ophthalmol 1967;77(6):761-8.

2. Khawam E, Ghazi N, Salti H. "Jampolsky Syndrome": superior rectus overaction-contracture syndrome: prevalence, characteristics, etiology and management. Binocul Vis Strabismus Q. 2000;15(4):331-42

3. Robinson D. Bielschowsky head tilt test II - Quantitative mechanics of the Bielschowsky head tilt test. Vis Rev. 1985;25(12):1983-8.

4. Bielschowsky A. Lectures on motor anomalies. Hannover: Dartmouth College Public 1943. p.73.

5. von Noorden GK, Campos E. Binocular vision and ocular motility. $6^{\text {th }}$ ed. St. Louis: Mosby; 2002. p.417.

6. Jampolsky A. A new look at the head tilt test. In: Fuchs AF, Brandt TH, Buttner U, Zee DS editors. Contemporary ocular motor and vestibular research: a tribute to David A. Robinson. Stuttgart, Ger: Thieme Verlag; 1994. p.432-9.

7. Souza-Dias C. Asymmetrical bilateral paresis of the superior oblique muscle. J-AAPOS 2007;11(1):12-6

8. Jampolsky AS. Surgical leashes and reverse leashes in strabismus surgical management. In: Symposium on Strabismus. Transactions of the New Orleans Academy of Ophthalmol. St. Louis: Mosby; 1978. p.244.

9. Wong AM, Colpa L, Chandrakumar M. Ability of an upright-supine test to differentiate skew deviation from other vertical strabismus causes. Arch Ophthalmol. 2011; 129(12):1570-5.

10. Bicas HE, De Sordi GB. Contradições nos resultados de testes diagnósticos de desequilíbrios verticais. In: Anais do XVI Congresso Brasileiro de Oftalmologia, Campinas (SP); 1971. Conselho Brasileiro de Oftalmologia; 1971. p.132.

11. Prieto-Díaz J, Souza-Dias C. Estrabismo. Buenos Aires, Ediciones Científicas Argentinas; 2005. p.324

12. Souza-Dias C, Goldchmit M. Os estrabismos: teoria e casos comentados. Rio de Janeiro: Cultura Médica; 2011. p.289-91. 